\section{Psychic Unity}

Marta Facoetti and Nathalie Gontier

Applied Evolutionary Epistemology Lab, Centro de Filosofia das Ciências, Departamento de

História e Filosofia das Ciências, Faculdade de

Ciências, Universidade de Lisboa, Lisbon,

Portugal

\section{Synonyms}

Cognitive universals; Human nature; Human universals

\section{Definition}

The "psychic unity" idea denotes the existence of a set of psychological and cognitive capacities universally shared by human beings and grounded in biological equality.

\section{Introduction}

The psychic unity idea assumes that all humans share cognitive and linguistic capacities that are grounded in biology and that uniformly underlie how we relate to one another and to the world we live in, regardless of differential cultural upbringing. This chapter is divided into three sections. In the first section, we detail how the idea originates in ancient Greek philosophy and how throughout the ages it has spread toward the different sociocultural and linguistic disciplines. In the second part, we discuss how today, researchers in the cognitive, behavioral, and cultural sciences are providing a new biological foundation to the search for human universals. And in part three, we point toward current debates on the nature and tenability of the idea of a psychic unity.

\section{History of the Concept}

The psychic unity idea, or the idea that there exists an essential and uniform human nature made up of shared sensorial and reasoning capacities sometimes rendered with the notions of a "shared human nature" or "human universals," has its roots in ancient Greek philosophy. Subsequently, it has spread throughout Western philosophical, religious, and humanist thought where it has been reinterpreted multiple times over. Common to all notions of a psychic unity is the adherence to assumptions on shared cognitive, cultural, and linguistic capacities which are contrasted from notions of particularity and relativity of such capacities.

\section{The Philosophical Origins of the "Psychic Unity" Idea}

Plato (428/427-348/347 BC) and Aristotle (384-322 BC) are among the first to argue that all beings have an essence that makes them into 
what they are. On their account, what makes humans "human" is their intellectual soul that enables them to reason (Gontier 2009). By making use of their reasoning skills, humans are able to distinguish truths from falsehoods, whereby falsehoods are "bad" judgments informed by the use of the senses and truths are "good" judgments that rely on the use of the intellect. At night, for example, we falsely "perceive" the objects around us as black or gray, but we "know" that in truth, they have colors. But although differences in judgment occur due to making judgments either based upon reason or upon the senses, these thinkers assume that all humans are equipped with the same reasoning and perceptual capacities enabling them to make judgments in the first place.

Early Judeo-Christian thinkers agree that all human beings are endowed with both intellectual and instinctive capacities. For them, the intellect is a divine gift, while instincts are inspired by evil. Following one's reason or one's instincts becomes a matter of "free will," and differences in judgment result from choice inspired by faith or lack thereof.

From the seventeenth century onward, rationalists such as René Descartes (1596-1650) continue to endorse that all humans share a "universal reason" that they receive from a benign god, while empiricists such as John Locke (1632-1704), George Berkeley (1685-1753), and David Hume (1711-1776) introduce the notion of a "common sense" grounded in a universal way of perceiving the world through the senses. In so far as differences in reason exist, these are now understood to be of a cultural rather than a psychological kind (Gontier 2006, 3).

The encounter of non-Western nations with different cultural traditions makes moral philosophers such as Thomas Hobbes (1588-1679), JeanJacques Rousseau (1712-1778), and Adam Smith (1723-1790) distinguish between an individual or natural state wherein all human beings are equal and a societal or cultural state wherein linguistic, social, economic, and political differences exist (discussed in Gontier 2009). Due to a growing awareness of natural history, differences between societies and cultures are subsequently understood as resulting from an "unequal development" of common capacities along a hypothesized gradient of stadial sociocultural development that mimics the history of Western society, from hunter gathering over agricultural to industrial societies (Ingold 2006, 266).

\section{Human Variation in Times of Biological Racism}

In natural history studies and the early biological sciences, the encounter of non-Western cultural groups results in early attempts at explaining biological differences in terms of species variation. Carl Linnaeus (1707-1778) is one of the first scholars to divide the human species into five varieties: "Americans," "Europeans," "Asians," "Africans," and "Monsters." For the last category, Linnaeus draws upon a combination of false mythical tales as well as more concrete reports of humans with birth defects. The first four categories are based upon variation in physical features and geographical location, as well as assumed cultural temperaments which corresponds to what we would call stereotypes (Gould 1981).

Differential psychological and cultural traits thus become understood as biologically innate. And together with the varied physical appearance of human groups and their differential geographical dispersal, these traits become a means to debate unity and variation within our species. Scholars are thereby split into two camps. Georges-Louis Leclerc, Comte de Buffon (1707-1788), Johann Blumenbach (1752-1840), and James Cowles Prichard (1786-1848) maintain that all humans share a single origin (monogenism), while Charles White (1728-1813), Christoph Meiners (1747-1810), Thomas Jefferson (1743-1826), and Georges Cuvier (1769-1832) assume that the human species can be divided into varieties or "races" that each have historical origins independent from one another (polygenism).

In this regard, Charles Darwin (1809-1882), the founder of evolution theory, claims that behavioral traits and variation thereof are the outcome of evolution and that all humans share common descent with modification (monogenesis). But 
Darwin (1871) also endorses the false view that human varieties can be divided into "races" with morphological, psychological, and cultural differences that Darwin (1871) differentiates "races" morphologically, by different bodily characteristics (what we today call phenotypic differences), but also psychologically, by assuming differences in mental capacities and character traits, and culturally, by assuming different levels of "civilization." He furthermore assumes that these traits can be classified along progressive scales that bear connotations as going from "inferior" to "superior"- an idea that is further developed by Ernst Haeckel (1834-1919) with his biogenetic law.

\section{The Search for Universals in the Rising Psychological and Cultural Sciences}

The biological racism of the eighteenth and nineteenth century becomes systematically countered by rising psychological and anthropological schools of thought that again reinforce the idea of a psychic or mental unity among mankind. Going back to Immanuel Kant's (1724-1804) concept of pure reason and Johann Gottfried Herder's (1744-1803) idea of historical particularism, Theodor Waitz (1821-1864), Edward B. Tylor (1832-1917), and the ethnologist Adolf Bastian (1826-1905) argue for the existence of universally shared mental capacities (cf. Shore 2000; Jahoda 2013). Bastian (1881), in particular, distinguishes Elementargedanken or "elementary ideas" which are universal, fundamental, and timeless psychological structures whereby all humans organize experiences, from Völkergedanken or "folk ideas" which are historically particular and culture-specific ideas shared only by members of the same group. The group therefore has a form of social group mind which he calls a Gesellschaftsseele.

Franz Boas (1856-1942), father of American Anthropology and student of Bastian, uses the idea of a psychic unity of humankind in his long battle against biological racism. Echoing Rousseau, Boas reintroduces the nature-culture divide and distinguishes between particular cultural traditions rooted in different histories and universal, biologically underpinned mental endowment brought about by biological evolution (Shore
2000, 91-92). Humans are assumed to be biologically equal in having evolved the same and universal mental capacities that enable them to become cultural beings, while particular cultural traditions result from historical particularities and contingencies.

\section{Ideas of Psychic Unity in (Anthropological) Linguistics}

Moving forward to the twentieth century, Edward Sapir (1884-1939) and Benjamin Lee Whorf (1897-1941), two linguistic anthropologists of the Boasian school, further couple the doctrine of psychic unity with ideas on cultural relativism, and they introduce the latter into the study of language. While also retaining the idea of biological equality in psychological capacities, both Sapir (1929) and Whorf (1956) argue that the way wherein people conceptualize knowledge on the world is always relative to or even determined by the language they speak, so much so that languages underlie worldviews or specific views of the world, a view first introduced by Wilhelm von Humboldt (reviewed in Foley 1997, 197-201).

Sapir and Whorf's anthropological ideas on language also influence the general field of linguistics where, inspired by Eric Lenneberg's (1921-1975) notion of a "critical period" wherein language needs to be learned in order for it to be within the normal range, Noam Chomsky (1928-) subscribes to the existence of a biologically grounded faculty of language. This internal or I-language is characterized by a universal grammar (UG) and opposed to an external or E-language that is particular per individual and language. The former is grounded in biology and the latter in the language community where one forms part of.

In the beginning of the twentieth century, research on universal mental categories would furthermore start to include taboo concepts, kinship distinctions, color categories, etc. Regarding color categories, Brent Berlin (1936-) and Paul Kay (1934-), for example, and by continuing stage thinking and assuming the existence of ladders of complexity, famously argue that there are primary and universally shared color categories 
grounded in shared perception and that there is a nonrandom sequence in which cultures develop words to express these colors. Such research has nowadays evolved into the fields of folk psychology.

\section{The Biological Foundations of the Idea of Psychic Unity}

Today, we know that although humans vary phenotypically, we share the same genes, and the genetic distance between individuals, which is calculated to be $0,2 \%$, is the same for everyone (Cavalli-Sforza 2001). In other words, genetic differences are too minimal to divide the human species into races, and the different phenotypes we can distinguish are mere variations of the same kind of human. The neurological and cognitive sciences moreover demonstrate that all humans develop similar brain structures, and all normal individuals go through similar developmental stages.

Although there is general agreement on the fact that humans are endowed with alike cognitive structures, scholars are currently debating over which capacities are innate or instinctive and which are acquired or learned during development. On the one hand, instructionists maintain that our psychological and behavioral dispositions are acquired over the course of life through learning. On the other hand, nativists hold that both our basic physical-biological traits and our psychological structures are innate (Samet and Zaitchik 2017).

In the cognitive sciences, nativist and instructionist approaches go hand in hand with modular and anti-modular or domain-general conceptions of the mind. According to the modular or "mental organs approach," introduced by Chomsky (1980) and further elaborated by Jerry Fodor (1983), the mind is made up of many genetically determined domain-specific modules or mental organs (Samuels 1998, 577-579; Samet and Zaitchik 2017, 7). On the other side of the spectrum, inspired by Jean Piaget, supporters of the anti-modular approach endorse that our innate cognitive capacities are general purpose (Samuels 1998, 575).

Today, from generative linguistics to universalist cognitive science, from evolutionary psychology to universalist cultural anthropology, a number of contemporary scholars work under the assumption of evolved and therefore innate mental competences to substantiate their universalist claims.

By drawing upon Chomsky's work on UG, generative linguists seek to discover "the cognitive (and hence universal) foundations of language" (Haspelmath 2012, 92). In doing so, they maintain that human beings share a distinct "language faculty" or "innate specialization for language." On this view, languages differ only superficially from one another, while on a deeper and structural level, they share a common set of syntactic rules.

Contrary to Chomsky, Joseph Greenberg, the father of linguistic typology, maintains that the existence of linguistic universals can only be deduced from the comparative analysis of many languages. By analyzing the structure of 30 languages, Greenberg (1963) has demonstrated that there exist various types of universals, some "absolute" and some others "statistical." Among the former, "unrestricted absolute universals" appear true of all languages (i.e., all languages have names and verbs, and all languages have vowels) and come close to the universals recognized by generative linguists (Evans and Levinson 2009, 437-438).

The idea of a psychic unity of humankind is also central to evolutionary psychology. Evolutionary psychology propounds a new "coherent framework for thinking about human nature and society" (Tooby and Cosmides 2005, 16), by maintaining that "a scientific definition of human nature" should focus on "the uniform architecture of the human mind and brain that reliably develops in every normal human just as do eyes, arms, a heart, and so on" (Tooby and Cosmides 1992, 209; quoted in Buller 2005, 428).

Examples are the study of innate or evolved mental competences in how we read other's behavior (folk psychology) or how we cognitively classify biological species (folk biology). As Scott 
Atran (1998, 567), who studies folk biology, explains "taxonomies plausibly represent 'modular habits' of the mind, naturally selected to capture recurrent habits of the world relevant to hominid survival in ancestral environments." Within this perspective, cognitive universalism and cultural particularism are ultimately reconciled: a universal system of classification is seen to underlie the development of different cultural classification systems. Evolutionary psychologists, such as David Buss, Leda Cosmides, Martin Daly, Steven Pinker, Todd Shackelford, Valerie Starratt, John Tooby, and Margo Wilson, identify human nature with the idea of a psychic unity of humankind which they define as "a set of psychological adaptations that are presumed to be universal among, and unique to, human beings" (Downes 2018) (cf. Tooby and Cosmides 2005, 39). On this view, psychological adaptations are evolved psychological mechanisms (Starratt and Shackelford 2010, 235) or modules (reviewed in Downes 2010, 244) that originated between 1.8 million and 10.000 years ago during the Pleistocene Epoch and that helped our ancestors to deal with a number of adaptive problems (Starratt and Shackelford 2010, 231-235; cf. Downes 2018). As Starratt and Shackelford (2010, 232-238) point out, although such psychological mechanisms evolved to respond to inputs present in our ancestors' environment and although such mechanisms are genetically hardwired and did not change over the last 10,000 years, their output is far from being "staunchly predetermined," as our behavior is also variously influenced by the environments that we currently inhabit. Along these lines, by claiming that individual variation emerges from "a common nature" attending to different inputs or circumstances, evolutionary psychologists find a way to reconcile human diversity - whether it being cultural, linguistic, or behavioral - with the idea of a psychic unity of humankind, that is, the notion of a "universal human nature" (Buller 2005, 72).

Today, evolutionary psychologists propose various arguments for the universality of psychological mechanisms or adaptations. Among others, Cosmides and Tooby (1997) propose what David Buller dubs "the argument from
Gray's Anatomy" and "the argument from sexual recombination" (Buller 2005, 73). The former deduces the universality of "selection-designed psychological traits" from the universal character of "selection-designed morphological traits," on the grounds of the fact that everything, from our bodies to our minds, has been drafted by selection (Buller 2005, 73). The latter, on the other hand, infers the universality of all complex adaptations, such as psychological adaptations, from the fact that the genetic basis of adaptation necessarily imposes "species universality" (Buller 2005, 424). Furthermore, informed by research in cultural anthropology, evolutionary psychologists reaffirm the intimate connection between the psychic unity idea and an antiracist attitude toward the study of human behavior. As Tooby and Cosmides (1992, 38) explain “...models of a robust, universal human nature by their very character cannot participate in racist explanations of intergroup differences. (...) Human nature is everywhere the same."

\section{Contemporary Debate on the Idea of Psychic Unity}

Contemporary claims on the existence of a psychic unity of humankind have not remained uncontested. Today, universalist theories about language, cognition, psychology, and culture face the criticisms of a number of linguists, cognitive scientists, evolutionary psychologists, as well as philosophers. Contrasting arguments about the possibility of delineating the universal traits of a supposed human nature fuel contemporary debates about the idea of psychic unity, while some universalist approaches are undergoing a massive reshaping following the emergence of new data which demonstrate the existence of considerable crosslinguistic and cross-cultural variation as well as the nonuniquely human character of some traits that were previously thought to be distinctive of our species (Everett 2013, 21).

Today, adherents of generative linguistics cautiously distinguish between a "faculty of language in the broad sense (FLB)" and a "faculty of language in the narrow sense (FLN)" (Hauser et al. 
2002). On this view, whereas FLB can be found in humans and other species as well, the latter can be conceived as uniquely human (Hauser et al. 2002, 1578).

Linguistic typologists also use a more tempered language by understanding language universals as "tendencies," rather than "strict universals" or "uncontroversial facts" (Evans and Levinson 2009, 429-431), i.e., as properties that are common to many languages and whose identification necessarily requires to be "nonaprioristic," but based on the examination of "a sufficiently large and reasonably representative set of languages that have not influenced each other in recent times" (Haspelmath 2012, 91-99). Within linguistic typology, then language diversity ceases to be a mere superficial appearance and becomes a fact with "long historicocultural roots that explain the many divergences," which should be accepted and studied as such (Evans and Levinson 2009, 432). Such diversity, as Evans and Levinson $(2009,431)$ notice, reveals the centrality of "cultural and technological adaptation in our species: language is a bio-cultural hybrid, a product of intensive gene-culture coevolution over perhaps the last 200,000 to 400,000 years." In light of this, as language turns out to be not just a biological product, but also a culturalhistorical artifact, language and its universal tendencies need to be studied from within "a coevolutionary model" (Evans and Levinson 2009, 446). In addition, according to scholars in linguistic typology, the acknowledgement of the importance of culture for the development of human language allows one to go beyond the threat of ethnocentrism and the limitations of nativism that appear intrinsic to the generativist approach to linguistic universals (cf. Haspelmath 2012, 99; Evans and Levinson 2009, 445).

According to Evans and Levinson (2009), the above arguments have fundamental implications for the universalist approach to cognitive research too. In their opinion, the increasing evidence of structural language differences should lead cognitive scientists to stop searching for cognitive universals in the wake of generative linguistics and to develop "a new approach to language and cognition that places diversity at center stage," "a comparative psychology inside our own species in the central questions that drive cognitive science" (Evans and Levinson 2009, 429-432). Some cognitive scientists are already proposing such a comparative approach to cognitive research and point to the existence of crosscultural variation to challenge nativist approaches to folk psychology and folk biology (Ravenscroft 2019).

Universalist arguments in evolutionary psychology too have not gone unopposed. David Buller (2005), Stephen Downes (2010), John Duprè (2001), David Hull (1986), and Tim Ingold (2006) have similarly argued that the evolutionary psychological notion of human nature is untenable as it conflicts with evolutionary biology and does not take human variation into consideration. One for all, Buller (2005) puts forward five main critiques against such notion:

1. Both "the argument from sexual recombination" and "the argument from Gray's Anatomy" that Cosmides and Tooby (1997) propose in support of the universality of psychological adaptations are unwarranted (424). According to Buller, whereas the former can be rejected on the grounds of the fact that "selection can, and frequently does, maintain polymorphism of complex adaptations within populations" (424), the latter appears unsustainable because it rests upon "a questionable analogy between anatomy and psychology," among other things (425).

2. The notion of human nature relies on an arbitrary distinction between "normality" and "abnormality," which finds no support in contemporary biological theories (428-438).

3. The idea of human nature is based upon an essentialist view of species, but Buller shows that species are individuals, rather than natural kinds, and hence there cannot be "speciesspecific psychological laws" that apply uniquely to human beings (439).

4. Buller shows that, contrary to what evolutionary psychologists hold, the existence of cultural universals does not necessarily corroborate the idea of a universal human nature consisting of psychological universals 
(471). This is because psychological universals are not the only possible mechanisms that lead to cultural universals. The latter could instead derive from a number of other processes (462-471). (In this regard, some of the classic examples of human universals - Jay Odenbaugh 2015 cites inbreeding avoidance and incest taboos, while Rafael Nùñez 2017 refers to numerals - are demonstrably flawed: they are either too wide ranging to be uniquely human or too particular to represent universals of human nature (cf. Odenbaugh 2015, 9). Moreover, as Ingold 2006, Duprè 2001, and Nùñez 2017 argue, many of such examples are fundamentally Western centric. In light of this, although the psychic unity idea has undoubtedly contributed to the affirmation of human equality against racist claims, such notion appears to have a fundamental "reverse ethical significance" (Job 2006), whereby it would back the West's presumptions of superiority up by grounding human universals in Western principles and values (Ingold 2006, 262-279)).

5. For Buller, once we comprehend the true import of evolutionary theory, we will see that "our current adaptations" - whose roots evolutionary psychologists locate in the Pleistocene period - are "no more definitive of our 'nature' than past or future adaptations" (480) (cf. Downes 2010). In light of current evolutionary theory, it appears that our adaptations are "no more definitive of our 'nature' than nonuniversal adaptations and nonadaptations" (480).

Whereas Buller (2005), together with Hull (1986), Duprè (2001), Ingold (2006), and Odenbaugh (2015), remains skeptical about human nature, other scholars maintain that it is still possible to sensibly speak of human nature in biological terms (for an extensive review of some of the main arguments for and against the notion of human nature defended by evolutionary psychologists, see Downes (2018). Among others, Clark Barrett (2015) proposes to extend the evolutionary psychological notion of human nature to include human variation (reviewed in Downes 2018). Edouard Machery (2008), on the other hand, proposes a nomological notion of human nature, in opposition to an essentialist one. To Machery (2008, 322), Buller and Hull's critiques to human nature invalidate only the essentialist notion of human nature, which has its roots in folk biology and which understands human nature as "the [distinctive] set of properties that are separately necessary and jointly sufficient for being human." Machery (2008, 323; emphasis ours) thereby defends a nomological notion of human nature that interprets human nature as "the set of properties that humans tend to possess as a result of the evolution of their species." According to Machery $(2008,328)$, such nomological notion, and not the essentialist one, corresponds to the idea of psychic unity espoused by evolutionary psychologists.

Both Barrett's and Machery's theories are not spared from criticism. Whereas Barrett's view has been criticized for being a mere "big list of all the properties that humans have had and can have" (Downes 2018), Machery's has been attacked for giving rise to a "far more permissive" notion of human nature than he intended, leaving us wondering whether, today, a concept of human nature is still at all useful (Lewens 2015, 78-79).

\section{Conclusion}

Over the centuries, scholars in various disciplines have contributed to refining the conceptual contours of the psychic unity idea onward and upward. In so doing, they have sometimes come to tie it with contrasting theories, such as relativist and universalist interpretations of human worldview formation. In spite of the diverse usages of the psychic unity concept, its advocates have generally agreed in regarding the existence of uniform cognitive capacities as a proof of human equality.

Contemporary accounts of human universals, whether they are cognitive, linguistic, psychological, or sociocultural, remain ideas defended by some and criticized by others in all fields, including philosophy, psychology, anthropology, and linguistics. Proponents newly back up the psychic unity idea and its inherent ethical dimension by pointing to a shared evolutionary history, similar 
genetic endowment, alike brain structures, and common sociocultural values. On the other hand, some scholars oppose such idea by citing the radicality of human variability, the threats of Western-centrism, the limitations of nativism, and the importance of considering gene/culture coevolution for understanding human evolutionary development.

\section{Cross-References}

Controversies in Evolutionary Psychology
- Cross-Cultural Universality
- Cross-Cultural Variation
- Evidence of Brain Modularity
- Genetic Predispositions
- Groups and Categories
- Human Nature and Biocultural Evolution
- Individual Differences
- Language Acquisition
- Language Modularity
- Nativism
- Nature Versus Nurture
- Universal Aspects of Kinship
- Universal Grammar
- Universal Human Fears
- Why Humans Are Unique

Acknowledgments This work is financed by FCT, the Portuguese Foundation for Science and Technology, Grant ID DL57/2016/CP1479/CT0066 and Project ID: UIDB/00678/2020. (Este trabalho é financiado por fundos nacionais através da FCT - Fundação para a Ciência e a Tecnologia, I.P., no âmbito da Norma Transitória - DL57/ 2016/CP1479/CT0066; UIDB/00678/2020).

\section{References}

Atran, S. (1998). Folk biology and the anthropology of science: Cognitive universals and cultural particulars. Behavioral and Brain Sciences, 21, 547-609.

Barrett, H. C. (2015). The shape of thought: How mental adaptations evolve. Oxford: Oxford University Press.

Bastian, A. (1881). Der Volkergedanke Im Aufbau Einer Wissenschaft Vom Menschen. Berlin: Verlag von Ferdinand Dümmler.

Buller, D. (2005). Adapting minds: Evolutionary psychology and the persistent quest for human nature. Cambridge, MA: MIT Press.
Cavalli-Sforza, L. L. (2001). Genes, peoples, and languages. Berkeley: University of California Press.

Chomsky, N. (1980). On cognitive structures and their development: A reply to Piaget. In M. PiattelliPalmarini (Ed.), Language and learning: The debate between Jean Piaget and Noam Chomsky (pp. 35-52). Cambridge, MA: Harvard University Press.

Cosmides, L., \& Tooby, J. (1997). The modular nature of human intelligence. In A. B. Scheibel \& J. W. Schopf (Eds.), The origin and evolution of intelligence (pp. 71-101). Sudbury, MA: Jones and Bartlett.

Darwin, C. (1871). The descent of man, and selection in relation to sex (Vol. 1-2, 1st ed.). London: John Murray.

Downes, S. M. (2010). The basic components of the human mind were not solidified during the Pleistocene epoch. In F. Ayala \& R. Arp (Eds.), Contemporary debates in philosophy of biology (pp. 243-252). Oxford: Wiley Blackwell.

Downes, S. M. (2018). Evolutionary psychology. In Zalta, E. N. (Ed.), The Stanford encyclopedia of philosophy (Fall 2018 edition). https://plato.stanford.edu/archives/ fall2018/entries/evolutionary-psychology/. Accessed 18 Nov 2019.

Duprè, J. (2001). Human nature and the limits of science. Oxford: Clarendon Press.

Evans, N., \& Levinson, S. C. (2009). The myth of language universals: Language diversity and its importance for cognitive science. Behavioral and Brain Sciences, 32(5), 429-492.

Everett, C. (2013). Linguistic relativity: Evidence across languages and cognitive domains. Berlin: De Gruyter Mouton.

Fodor, J. (1983). The modularity of mind. Cambridge, MA: MIT Press.

Foley, W. A. (1997). Anthropological linguistics: An introduction. Oxford: Blackwell Publishers.

Gontier, N. (2006). Introduction to evolutionary epistemology, language and culture. In N. Gontier et al. (Eds.), Evolutionary epistemology, language and culture (pp. 1-29). Dordrecht: Springer.

Gontier, N. (2009). The origin of the social approach in language and cognitive research exemplified by studies into the origin of language. In H. Pishwa (Ed.), Language and social cognition: Expression of the social mind (pp. 25-46). Berlin: Mouton de Gruyter.

Gould, S. J. (1981). The mismeasure of man. New York: W. W. Norton \& Company.

Greenberg, J. H. (Ed.). (1963). Universals of language. Cambridge, MA: MIT Press.

Haspelmath, M. (2012). Escaping ethnocentrism in the study of word-class universals. Theoretical Linguistics, 38(1-2), 91-102.

Hauser, M. D., Chomsky, N., \& Fitch, W. T. (2002). The faculty of language: What is it, who has it, and how did it evolve? Science, 298(5598), 1569-1579.

Hull, D. L. (1986). On human nature. PSA (Proceedings of the Biennial Meeting of the Philosophy of Science Association), 2, 3-13. 
Ingold, T. (2006). Against human nature. In N. Gontier et al. (Eds.), Evolutionary epistemology, language and culture (pp. 259-281). Dordrecht: Springer.

Jahoda, G. (2013). Theodor Waitz on psychic unity. Integrative Psychological and Behavioral Science. https://doi. org/10.1007/s12124-013-9255-x. Accessed 22 June 2019.

Job, S. (2006). Psychic unity of humankind. Encyclopedia of Anthropology. https://doi.org/10.4135/9781412952453. n458. Accessed 22 June 2019.

Lewens, T. (2015). Cultural Evolution. Oxford: Oxford University Press.

Machery, E. (2008). A plea for human nature. Philosophical Psychology, 21, 321-329.

Nùñez, R. E. (2017). Is there really an evolved capacity for number? Trends in Cognitive Sciences, 21(6), 409-424.

Odenbaugh, J. (2015). Human nature and the problem of variation" (Rough draft). http://philsci-archive.pitt.edu/ 11552/. Accessed 02 Dec 2019.

Ravenscroft, I. (2019). Folk psychology as a theory. In Zalta, E. N. (Ed.). The Stanford encyclopedia of philosophy (Summer 2019 edition). https://plato.stanford.edu/ archives/sum2019/entries/folkpsych-theory/. Accessed 18 Nov 2019.

Samet, J., Zaitchik, D. (2017[2012]). Innateness and contemporary theories of cognition. In Edward N. Zalta (Ed.), The Stanford encyclopedia of philosophy (Fall 2017 edition), https://plato.stanford.edu/archives/fall2017/entries/ innateness-cognition/. Accessed 21 Nov 2019.
Samuels, R. (1998). Evolutionary psychology and the massive modularity hypothesis. British Journal for the Philosophy of Science, 49, 575-602.

Sapir, E. (1929). The status of linguistics as science. Language, 5, 207-214.

Shore, B. (2000). Human diversity and human nature. The life and times of a false dichotomy. In N. Roughley (Ed.), Being humans: Anthropological universality and particularity in transdisciplinary perspectives (pp. 81-103). Berlin/New York: De Gruyter.

Starratt, V. G., \& Shackelford, T. K. (2010). The basic components of the human mind were solidified during the Pleistocene epoch. In F. Ayala \& R. Arp (Eds.), Contemporary debates in philosophy of biology (pp. 231-242). Oxford: Wiley Blackwell.

Tooby, J., \& Cosmides, L. (1992). The psychological foundations of culture. In J. H. Barkow, L. Cosmides, \& J. Tooby (Eds.), The adapted mind: Evolutionary psychology and the generation of culture (pp. 19-136). New York: Oxford University Press.

Tooby, J., \& Cosmides, L. (2005). Conceptual foundations of evolutionary psychology. In D. Buss (Ed.), The handbook of evolutionary psychology (pp. 5-67). Hoboken, NJ: Wiley.

Whorf, B. L. (1956). Language, thought, and reality. Selected writings of Benjamin Lee Whorf. Cambridge, MA: The MIT Press. 